\title{
Development of polyploid pollen grains in alfalfa (Medicago media Pers.)
}

\section{J. CEBRAT}

Among the alfalfa specimens examined plants were found with pollen grain of abnormal size. Some of these plants produced only pollen grains larger than normal, whereas others had grains of various sizes. The present paper describes the course of sporogenesis and pollen grain development and gives a comparison of pollen fertility in the individuals exhibiting various pollen types.

\section{MATERIAL AND METHODS}

The plants producing normal pollen grains will be denoted as $\mathrm{N}$, those with large grains as G (giant) and those with grains of various size as D (different).

Among the about 100 populations examined from various localities (about 5000 individuals) the plants G and D were found only in two of them. In Puławy eight individuals of the $G$ type and 24 individuals of the D type were found. It appeared that all these individuals were related. They arose as the result of inbreed of one plant (no. 33) and cross-pollination with the same plant (Tab. 1, p. 488). In Szelejewo in one plot four individuals of the D type were found. Since they occured on the same plot, it is probable that here too they were related.

For the investigations on microsporogenesis and pollen grain development one individual of each type (i.e. N, D, G) was chosen from the progeny of the plant no. 33. The studies were made on permanent and stained microtome preparations. The flower buds were fixed in CrAF $(0.5-0.5-20)$. They were then dehydrated with ethyl and n-butyl alcohols, imbedded in paraffin of increasing concentrations in n-butyl alcohol. Sections $6-7 \mu$ thick were stained with basic fuchsine and with fast green according to the further described so far unpublished method of Prof. H. Teleżynski. After deparaffination in xylene the slides were passed through a series of decreasing ethanol concentrations to water. They were then hydrolysed (like for the Feulgen reaction) in $1 \mathrm{~N} \mathrm{HCl}$ for 10-12 min. at $60^{\circ} \mathrm{C}$ and transferred to an 0.5 percent basic fuchsine solu- 
tion in McIlvaine's buffer pH 2.6 (P e a r se 1957) for $1-2$ hrs. After staining the preparations were washed in a tenfold dilution of the buffer $\mathrm{pH} 2.6$ and passed through a series of increasing ethanol concentrations to a 0.5 percent fast green solution in 96 percent ethanol for several seconds, and then through absolute alcohol and xylene and they were monted in balsam.

The pollen fertility was determined by the reaction with sudan IV. The pollen grains with staining content were considered as living and the colourless ones as abortive.

\section{RESULTS}

Plate I shows the pollen grains produced by three types of individuals $\mathrm{N}, \mathrm{G}$ and $\mathrm{D}$. The diameter of the large pollen grains produced by $\mathrm{G}$ is about 1.6 times the size of those produced by $\mathrm{N}$, this giving an about 4 -fold difference in their volume. In the D individual four types of pollen grains can be distinguished: a) normal grains in size and shape like in $\mathrm{N}, \mathrm{b}$ ) spherical large grains of the same size as in $\mathrm{G}, \mathrm{c}$ ) oval grains with one diameter equal to that of normal grains and a larger diameter like that of the large grains, d) large grains of irregular shape.

Cytological analysis demonstrated that miorosporogenesis in the individuals studied was typical for alfalfa (Grun 1951; N ic ol off 1963; R a usch 1964; Cebrat 1967) up to the moment of nuclear tetrad formation. In alfalfa the tetrads are formed as the result of meiotic divisions of the pollen mother cell (PMC) without cytokinesis after the first meiotic division. This is characteristic for the simultaneous type of PMC division.

Plate II shows the development of normal pollen grains in an $\mathrm{N}$ individual (figs 2-4) and of large pollen grains in G (figs 5-10) after formation of a nuclear tetrad (fig. 1). In the $\mathrm{N}$ individual the tetrad of nuclei is divided as the result of cytokinesis into a tetrad of mononuclear haploid microspores (fig. 2) which continue their development leading to the formation of normal pollen grains with haploid generative and vegetative cells (fig. 4). The development of large pollen grains is quite different. The main difference consists in that cytokinesis does not occur after the second meiotic division. Owing to this four-nucleate cells surronded with exine are formed (fig. 5). Their nuclei, owing to progressing vacuolization of the cells, are shifted to one of the poles. In this position the nuclei enter synchronically the phase of mitotic division (fig. 6). The chromosomes of all four nuclei form as a rule one common metaphasal plate (fig. 8). Only seldom was the formation of two plates observed (fig. 7). The further course of mitosis is normal (fig. 9), ending in cytokinesis and formation of tetraploid vegetative and generative cells (fig 10). When 


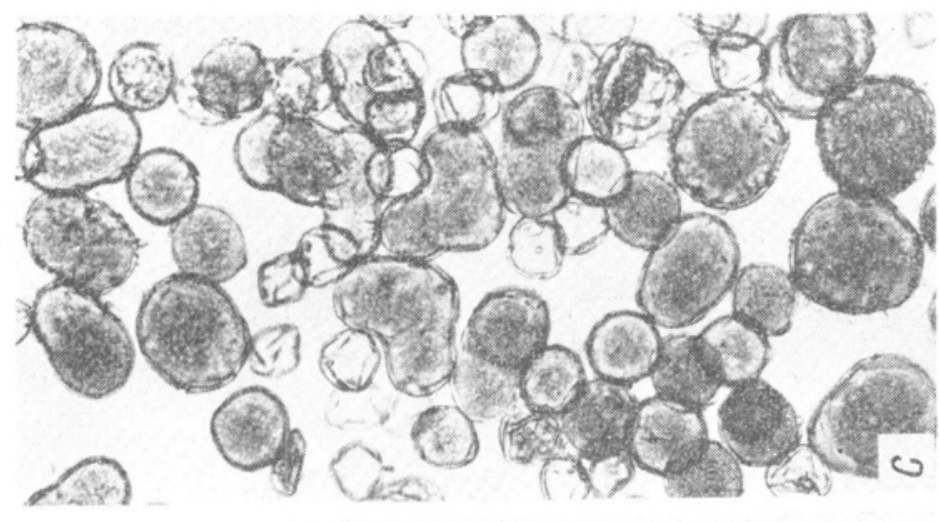

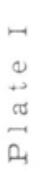
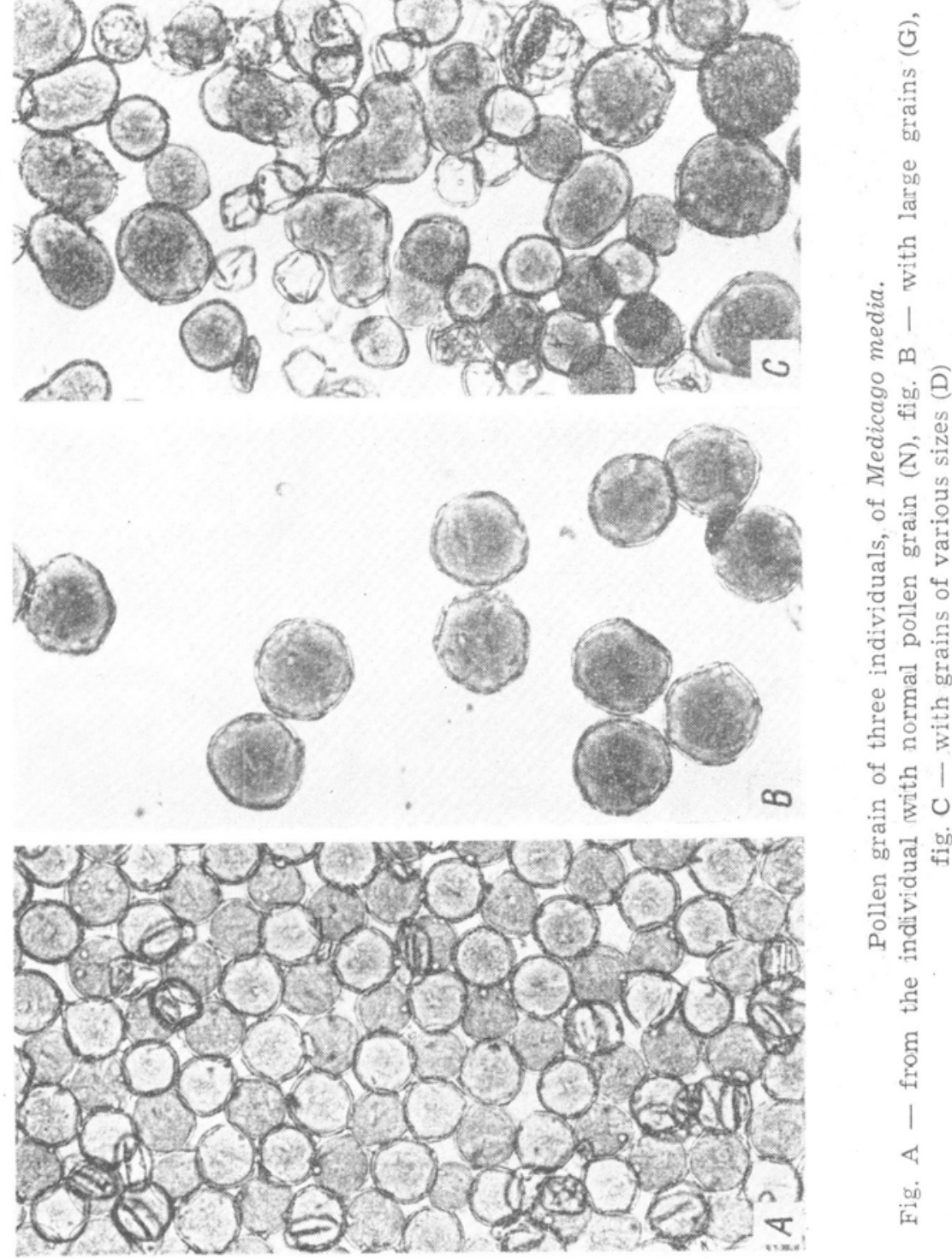


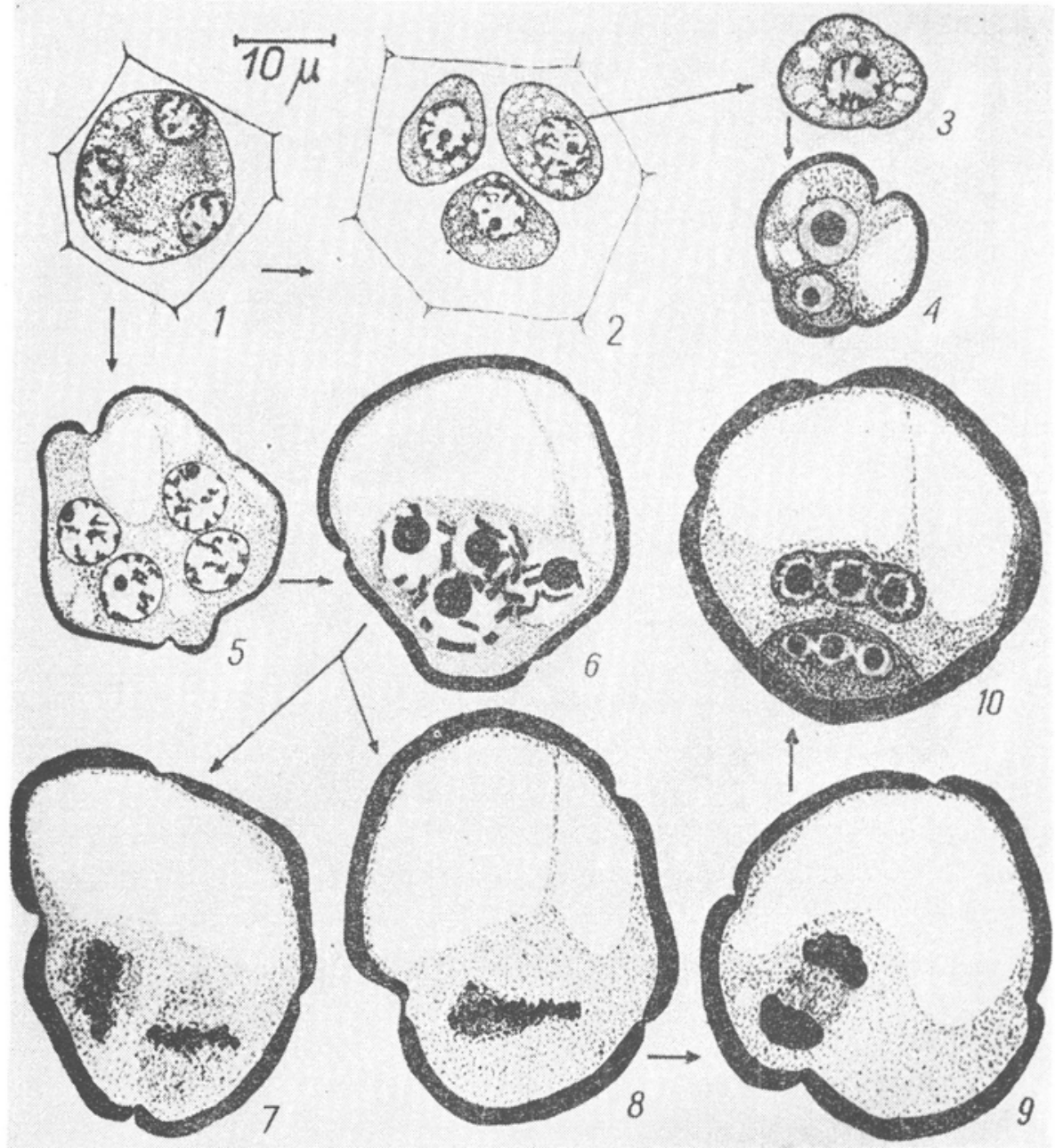

Development of pollen grains in two individuals of Medicago media with normal $(\mathrm{N})$ and large $(\mathrm{G})$ pollen grains.

Figs 1-4 development of normal grains, figs 5-10 development of large grains

two metaphasal plates are formed, they give rise to two diploid generative cells and a two-nucleate vegetative cell. Pollen grains of this type were only rarely observed and their further fate is not known.

Plate III presents the development of pollen grains of individual D. In this plant similarly as in the two previously described ones a tetrad of nuclei arises as the result of meiotic division of the PMC (fig. 1). Its 


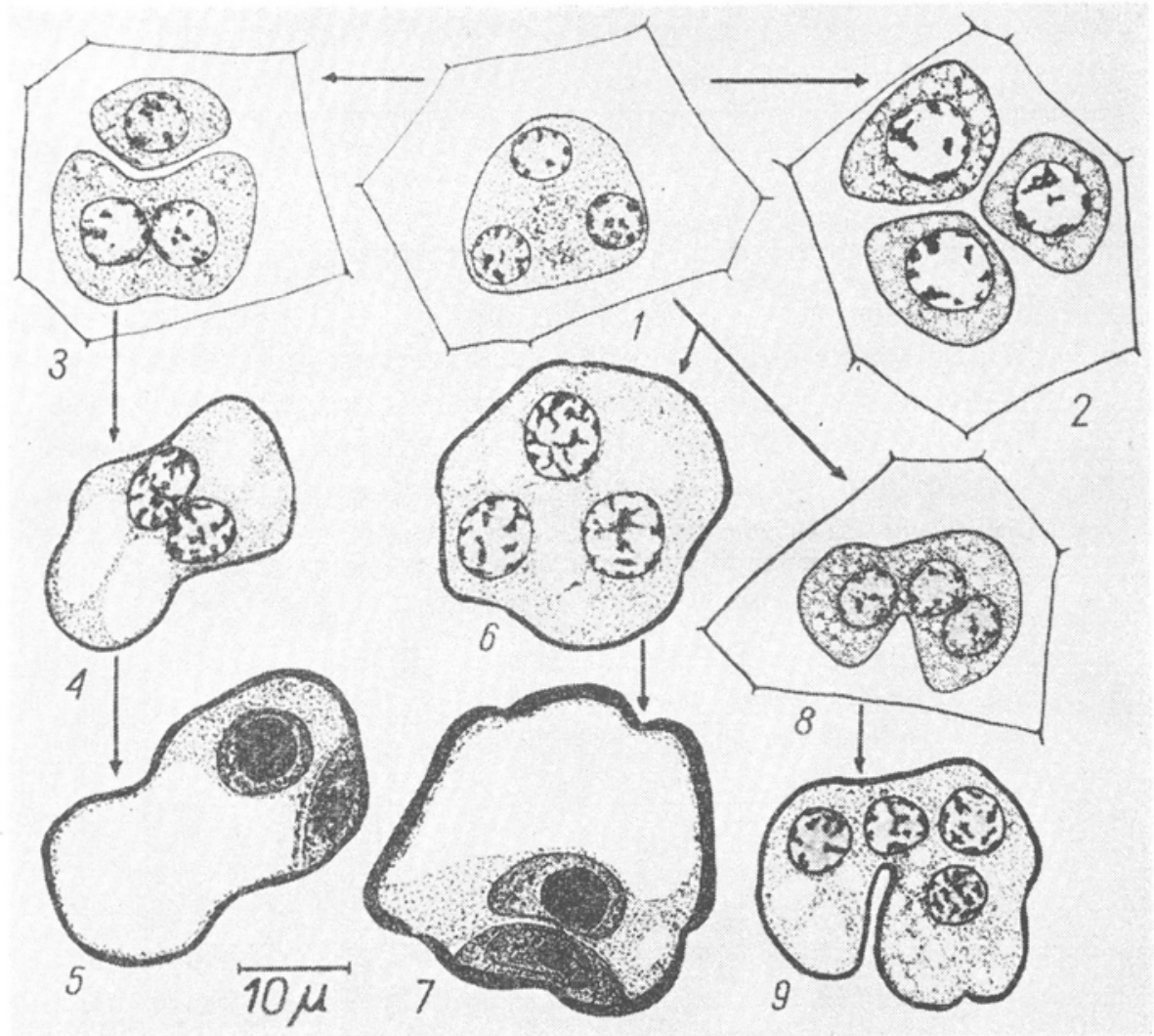

Development of pollen grains in the individual of Medicago media producing pollen grains of various sizes (D)

further development in D may vary even within one pollen sac. The two possibilities are following: I. The nuclear tetrad undergoes cytokinetic division leading to the formation of a tetrad of haploid microspores (fig. 2) which develop further to normal haploid pollen grains as in the $\mathrm{N}$ individual. Thus, in D individuals pollen grains of normal size may be found beside the atypical ones. II. Cytokinesis is more or less inhibited. If it is completely arrested, four nucleate cells are formed (fig. 6) which develop according to the above described mode into the tetraploid large pollen grains (fig. 7) of the same type as those in G individuals. The tetraploid pollen grains also are formed as the result of partial incomplete cytokinesis (figs 8 and 9). Incomplete cytokinesis leads sometimes to the division of the tetrad of nuclei into two binucleate sister cells (fig. 5). These cells 
Table 1

Specimens with abnormal pollen grains in Puławy

\begin{tabular}{|c|c|c|c|c|}
\hline & \multirow{2}{*}{$\begin{array}{c}\text { No. of } \\
\text { specimens } \\
\text { examined }\end{array}$} & \multicolumn{3}{|c|}{ No. of individuals with pollen grains } \\
\hline & & normal & $\begin{array}{c}\text { of various } \\
\text { sizes }\end{array}$ & large \\
\hline $\begin{array}{l}F_{1}-33 \\
F_{1}-33 \times 210 \\
F_{1}-206 \times 33\end{array}$ & $\begin{array}{l}38 \\
57 \\
49\end{array}$ & $\begin{array}{l}15 \\
53 \\
44\end{array}$ & $\begin{array}{r}17 \\
3 \\
4\end{array}$ & $\begin{array}{l}6 \\
1 \\
1\end{array}$ \\
\hline
\end{tabular}

in further development transform to diploid, oval pollen grains (figs 4 and 5). Thus the individual D produces three types of pollen grains with respect to the number of chromosomes: ha- di- and tetraploid ones.

Table 2

Comparison of number of disturbed meiotic anaphases in PMC with number of abortive pollen grains in $\mathrm{N}, \mathrm{G}$ and $\mathrm{D}$ individuals

\begin{tabular}{|c|c|c|c|}
\hline \multirow[t]{2}{*}{ Individual } & \multicolumn{2}{|c|}{$\begin{array}{l}\text { Abnormal meiotic } \\
\text { anaphases, } \%\end{array}$} & \multirow{2}{*}{$\begin{array}{c}\text { Abortive } \\
\text { pollen } \\
\text { grains, \% }\end{array}$} \\
\hline & I & II & \\
\hline $\mathrm{N}$ & 18 & 24 & 13 \\
\hline $\mathrm{G}$ & 66 & 37 & 4 \\
\hline $\mathrm{D}$ & 26 & 18 & 22 \\
\hline
\end{tabular}

In all three individuals numerous disturbances in the chromosome separation during meiosis were observed like formation of bridges, lagging chromosomes in anaphase I and II what led finally to the formation of micronuclei. Table 2 shows the percentage of disturber meiotic anaphases in PMC and the percentage of abortive pollen grains in the individuals studied. Comparison of these values shows that in all three cases the percentage of disturbed meiotic anaphases is larger than the percentage of abortive pollen grains. Particularly wide differences were noted in G. In the $\mathrm{N}$ and $\mathrm{D}$ individuals the meiotic disturbances caused the pollen grains to degenerate in a much higher extent than in G.

One might attribute the differences in pollen fertility in the three plants examined to some accidental causes. Therefore the fertility of pollen from other plants of different types was studied (Table 3 ).

As seen from this table the pollen fertility in $N$ and $D$ individuals is much lower than in the $G$ one. The fertility in all the six G specimens exceeded 90 percent.

The reason for this difference and high fertility of large pollen grains becomes clear in the light of presented previously data on dovelopment 
Table 3

Pollen fertility in individuals of 1st generation of the inbreed plant 33 from Pulawy

\begin{tabular}{c|c|c|c} 
Pollen & \multicolumn{4}{|c}{ No. of individuals } \\
fertility, \% & N & D & G \\
\hline $30-40$ & 2 & 2 & - \\
$40-50$ & 4 & 6 & - \\
$50-60$ & 3 & 6 & - \\
$60-70$ & 4 & 2 & - \\
$70-80$ & 1 & 1 & - \\
$80-90$ & 1 & - & - \\
$90-100$ & - & - & 6 \\
\hline
\end{tabular}

of pollen grains in the different plant types. The disturbances which lead to loss of some chromosomes may be lethal for the haploid pollen grains. In polyploid grains, however, the loss of one or even more chromosomes as the result of micronuclei formation may be of no major importance for the survival of the grains, on account of the presence of other chromosomes homologous to those which were lost. Probably a large part of the polyploid pollen grains is, owing to the numerous meiotic disturbances, of the aneuploid type but still is normally developed.

\section{DISCUSSION}

The present paper gives a description of one of the pathways leading in alfalfa to polyploidization of pollen grains. In this case polyploidization occured by way of partial or complete inhibition of cytokinesis after the second meiotic division of the pollen mother cells.

According to the principle that the development of cells and organisms is the function of genes and of environment we must admit that also the development of pollen grains is conditioned genetically as well as enviromentally. Which factor causes the disturbances of postmeiotic cytokinesis in the G and D individuals? The definite character of the disturbance and the existence of the $\mathrm{G}$ individuals producing exclusively tetraploid pollen grains speaks in favour of the supposition that a defect of the genetic system regulating cytokinesis is involved here. However, the formation in plants of $\mathrm{D}$ type of various types of pollen grains points to the susceptibility of the cytokinesis mechanism to the influence of the environment (the latter includes also the surrounding cells). This would mean that the given genetic system ceases to be infallible. May be, this defect of the genetic system in these plants is of such type that these plants will be capable in certain external conditions to produce only normal pollen grain, whereas in other conditions only tetraploid grains. 
It should be mentioned that in plants producing haploid pollen grains appropriately selected components of the external environment may induce disturbances in cytokinesis leading to polyploidization of some of the pollen grains (S a x 1937; G il e s 1939).

It is noteworthy that cytokinesis inhibition in the PMC of plants growing in natural conditions concerns polyploids, hybrids and apomicts (Maheshwari 1949; Church 1936; Castetter 1925; Edman 1937), i.e. plants characterized as a rule by numerous meiotic disturbances (Stebbins 1959). Medicago media Pers. is not an exception here, it is a cross between M. sativa L. and M. falcata L. and exhibits many meiotic disturbances ( $\mathrm{R}$ a u s ch 1964; C e b r a t 1967). Similar meiotic disturbances occur also in the related species M. stativa L. (G r u n 1951; $\mathrm{Nic}$ ol off 1963). All the three individuals investigated exhibited many disturbances in the chromosome separation in PMC meiosis. It would seem that the cytokinesis disturbance in the PMC of these plants are a consequence of the meiotic disturbances which occured in their ancestors.

\section{SUMMARY}

The paper describes the course of microsporogenesis and the development of pollen grains in the individuals of the hybrid alfalfa (Medicago media Pers.) producing pollen grains of various types: a) only normal, b) only large, and c) of various sizes. The course of microsporogenesis in the individuals studied was the same up to the moment of formation of the tetrads of nuclei. The factor decisive for the change in development towards formation of large and varied pollen grains is the complete or partial inhibition of cytokinesis which normally occurs after the second meiotic division. As the result of complete cytokinesis inhibition, what is characteristic for the individuals producing only large pollen grains, four - nucleate cells surrounded with exine are formed. The nuclei enter synchronously the mitotic division and the chromosomes form then as a rule one common metaphasal plate. This leads finally to fertile tetraploid pollen grains. In individual with pollen grains of various size cytokinesis has either a normal course or is more or less inhibited. Owing to th:s ha-, di- and tetraploid pollen grains arise.

In view of the specific definite character of the disturbance leading to the formation of polyploid pollen grains, and the occurence of this disturbance only within the groups of related planits, it would seem that this disturbance is due to a genetic defect.

All the three individuals examined exh:bited many disturbances in chromosome separation during meiotic division I and II (bridges, lagging chromosomes). The percentage of degenerating pollen grains was lower in all cases than that of the pollen mother cells with disturbed meiotic divisions. Particularly wide differences were noted in the individual producing tetraploid pollen grains. 
The paper was prepared in collaboration with the Group for Breeding and Cultivation of Alfalfa, Polish Academy of Sciences. The author wishes to thank Dr. Z. Hejnowicz for valuable advice and Dr A. Jelinowska and eng. H. G a carzewicz for making available to him their plant collection and for their help in examination of plants.

\section{Dept of Plant Anatomy}

and Cytology Univ. of Wroclaw, ul. Kanonia 6, Wroclaw

(Entered. January 29, 1969)

\section{REFERENCES}

Castetter E. F., 1925, Studies on the comparative cytology of the annual and biennial varieties of Melilotus alba, Amer. J. Bot. 12: 270-286.

C e br a t J., 1967, Preliminary embryological investigations on the cause of lowered fertility of Medicago media Pers, var. Kleszozewska, Acta Agroboitanica 20: 71-86 (in Polish with English summary).

Church G. L., 1936, Cytological studies in the Graminae, Amer. J. Bot. 23: 12-15. Edman G., 1937, Apomeiosis and apomixis bei Atraphaxis frutenscens C. Koch., Acta Horti Bergiani 11: 13-66.

Giles N., 1939, The effect of dehydration on microsporogenesis in Tradescantia, Amer. J. Bot. 26: 334-339.

Grun P., 1951, Variation in the meiosis of alfalfa, Amer. J. Bot. 38: 475-482.

M a h e s hw a ri P., 1949, The male gametophyte of Angiosperms, Bot. Rev. 15: 1-75. Nicoloff H., 1963, Citologiczeskogo i embriologiczeskogo prouczwanie na Medicago sativa L. $(2 \mathrm{n}=4 \mathrm{x}=32)$, Bullet. Inst. Cult. Plant. 16: 57-70.

P e a r e A.G.E., 1957, Histochemia teoretyczna i stosowana, PZWL, Warszawa.

R a us ch H., 1964, Ursachen der Infertilität der Luzerne (Medicago media Pers.).

Untersuchungen über Korrelation zwischen samenertragsbedingenden Factoren,

Z. Pfl. Zuchtung 51: 141-166.

$\mathrm{S}$ a x K., 1937, Effect of variation in temperature on nuclear and cell division in Tradescantia, Amer. J. Bot. 24: 218-225.

S t e b bin s G. L., 1958, Zmienność i ewolucja roślin, PWN, Warszawa.

Rozwój poliploidalnych ziarn pylkowych u lucerny-Medicago media Pers.

Streszczenie

W pracy opisano przebieg mikrosporogenezy i rozwój ziarn pyłkowych u trzech osobników lucerny mieszańcowej różniących się typem produkowanego pyłku: a) tylko normalnej wielkości ziarna pyłkowe, b) tylko duże kuliste ziarna pyłkowe, c) ziarna pyłkowe o różnej wielkości i kształcie. Stwierdzono, że przeb:eg mikrosporogenezy był taki sam do momenitu utworzenia się tetrady jąder u wszystkich trzech osobników. Czynnikiem powodującym wystapp:enie różnic było całkowite lub 
częściowe zahamowanie cytokinezy, która normalnie wystẹpuje po drugim podziale mejotycznym. W wyniku calkowitego zahamowania cytokinezy u osobnika produkującego tylko duże ziarna pyłkowe powstawały czterojądrowe mikrospory otoczone egzyną. Jądra takiej mikrospory wstępowaly jednocześnie w podzial mitotyczny, a chromosomy tworzyły jedną wspólną płytkę metafazową. W rezultacie tworzyły się tetraploidalne ziarna pyłkowe. U osobnika o ziarnach pyłkowych różnej wielkości, cytokineza po drugim podziale mejotycznym przebiegała albo normalnie, albo byla mniej lub bardziej zahamowana, w wyniku czego powstawały ziarna pyłkowe ha-, di- i tetraploidalne.

Ze względu na określony charakter zaburzenia prowadzący do tworzenia się poliploidalnych ziarn pyłkowych, oraz na występowanie tego zaburzenia tylko w kręgu roślin spakrerwnionych można sądz:ć, że zaburzenie to jest spowodowane defektem genetycznym.

Wszystkie trzy badane osobniki chanakteryzowaly się licznymi zaburzeniami w rozdziale chromozomów w czasie I-go i II-go podziału mejotycznego (mostki, gubiące się chromozomy). Procent degenerujących ziarn pyłkowych był we wszystkich przypadkach mniejszy od procentu komórek macierzystych pyłku o zaburzonych podziałach mejotycznych. Szczególnie duże różnice zaznaczyły siẹ u osobnika produkującego ziarna pyłkowe tetraploidalne. 